\section{Validation of the reported occurrence of Tajuria maculata, the Spotted Royal butterfly (Lepidoptera: Lycaenidae), in the Western Ghats, southwestern India, on the basis of two new records}

\author{
Vivek Kumar Sarkar ${ }^{1}$, Daniel Sukumar Das ${ }^{2}$, \\ V.C. Balakrishnan ${ }^{3}$ \& Krushnamegh Kunte ${ }^{4}$ \\ ${ }^{1}$ Bidhu Bhawan, Rajmata Road, OPO Block, Coochbehar, West \\ Bengal 736101, India \\ ${ }^{2}$ No. $42,3^{\text {rd }}$ Main Road, K.S. Town, Bengaluru, Karnataka \\ 560060 , India \\ ${ }^{3}$ Society for Environmental Education in Kerala (SEEK), Edat \\ P.O., Kannur, Kerala 670327, India \\ ${ }^{4}$ FAS Center for Systems Biology, Harvard University, 52 Oxford \\ St., Cambridge, MA 02138, USA \\ Email: ${ }^{4}$ krushnamegh@ifoundbutterflies.org (corresponding \\ author)
}

Tajuria maculata (Hewitson, 1865) (Lepidoptera, Lycaenidae, Theclinae, Iolaini), popularly known as the Spotted Royal, is a widespread oriental butterfly (Image 1). It ranges from the central Himalaya and northeastern India to South China, Indo-China, peninsular Malaysia and Borneo. No valid subspecies are currently recognized in this vast region (Evans

Date of publication (online): 26 March 2011

Date of publication (print): 26 March 2011

ISSN 0974-7907 (online) | 0974-7893 (print)

Editor: Peter Smetacek

\section{Manuscript details:}

Ms \# 02645

Received 07 December 2010

Final received 07 March 2011

Finally accepted 10 March 2011

Citation: Sarkar, V.K., D.S. Das, V.C. Balakrishnan \& K. Kunte (2011) Validation of the reported occurrence of Tajuria maculata, the Spotted Roya butterfly (Lepidoptera: Lycaenidae), in the Western Ghats, southwestern India, on the basis of two new records. Journal of Threatened Taxa 3(3): 1629-1632.

Copyright: ( ) Vivek Kumar Sarkar, Daniel Sukumar Das, V.C. Balakrishnan \& Krushnamegh Kunte 2011. Creative Commons Attribution 3.0 Unported License. JoTT allows unrestricted use of this article in any medium for non-profit purposes, reproduction and distribution by providing adequate credit to the authors and the source of publication.

Acknowledgements: VKS and DSD are grateful to the Karnataka Forest Department for the permission to conduct field work at the Brahmagiris, and to Kumar Ghorpade for logistical support. The specimen depicted in Image 1 is from the Museum of Comparative Zoology (MCZ), Harvard University; thanks to Naomi Pierce (Curator of Lepidoptera, MCZ) and Philip Perkins (Collections Manager, MCZ) for permission and Rod Eastwood (Post-doctoral Research Fellow, MCZ) for his assistance in locating and photographing the specimen. This is Publication No. 2 of the Indian Foundation for Butterflies (http://ifoundbutterflies.org/).

\section{OPEN ACCESS | FREE DOWNLOAD (C) (1) (1)}

1932; Pinratana 1981; Smith 1989; Corbet et al. 1992; Io 2000; Inayoshi 2010). It is uncommon to rare throughout its range, although reportedly common in the Khasi Hills (Swinhoe 19111912), and usually associated with montane habitats between 1,000-1,500 m (Wynter-Blyth 1957; Smith 1989; Corbet et al. 1992). Within the Indian subregion, it has been reported from central to eastern Nepal (Smith 1989), Sikkim and the eastern Himalaya, Sibsagar in eastern upper Assam, the Khasi and Naga Hills in northeastern India, and from Myanmar (de Nicéville 1890; Swinhoe 1911-1912; Wynter-Blyth 1957), but not from Bangladesh (Larsen 2004). It is at least bivoltine, being reportedly on the wing in March, May, September and October in Nepal, June, July and November in the Khasi Hills, and May in the Naga Hills (Wynter-Blyth 1957; Smith 1989). Its early stages have recently been studied in Hong Kong (http://www.hkls.org/info-t_maculata.html).

The only Western Ghats record of T. maculata is in the de Nicéville collection, a single specimen that Stokes

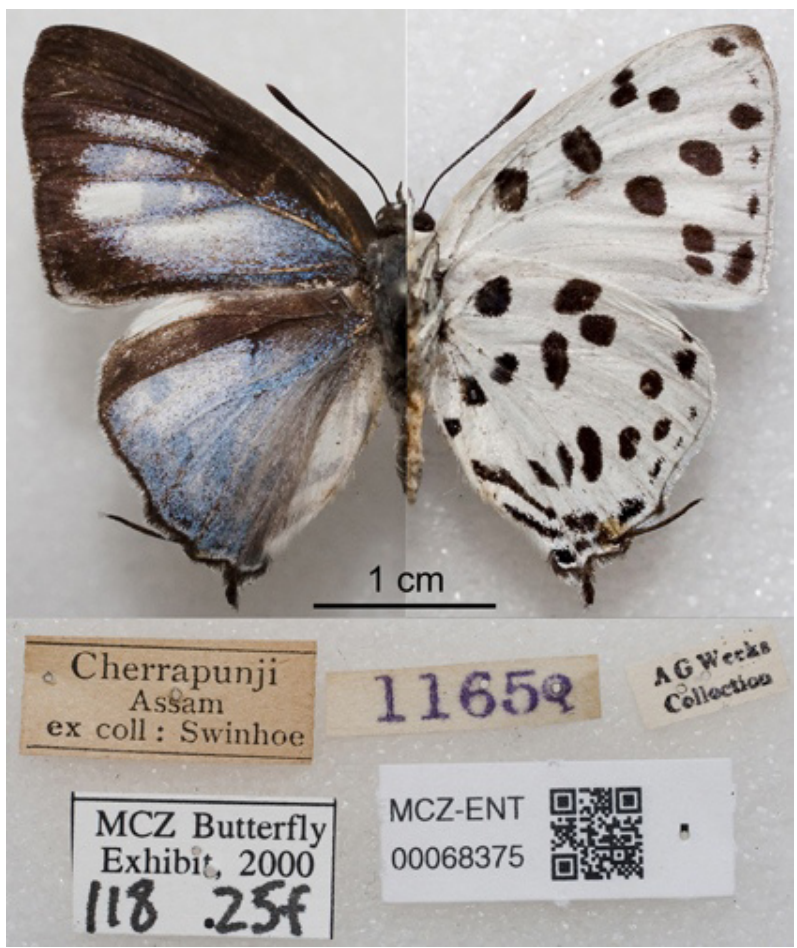

Image 1. Tajuria maculata: male specimen taken at Cherrapunji, eastern Meghalaya, northeastern India. Left shows the upper side, right shows the underside of the same specimen (Photographs: Krushnamegh Kunte; (C) President and Fellows of Harvard College) 


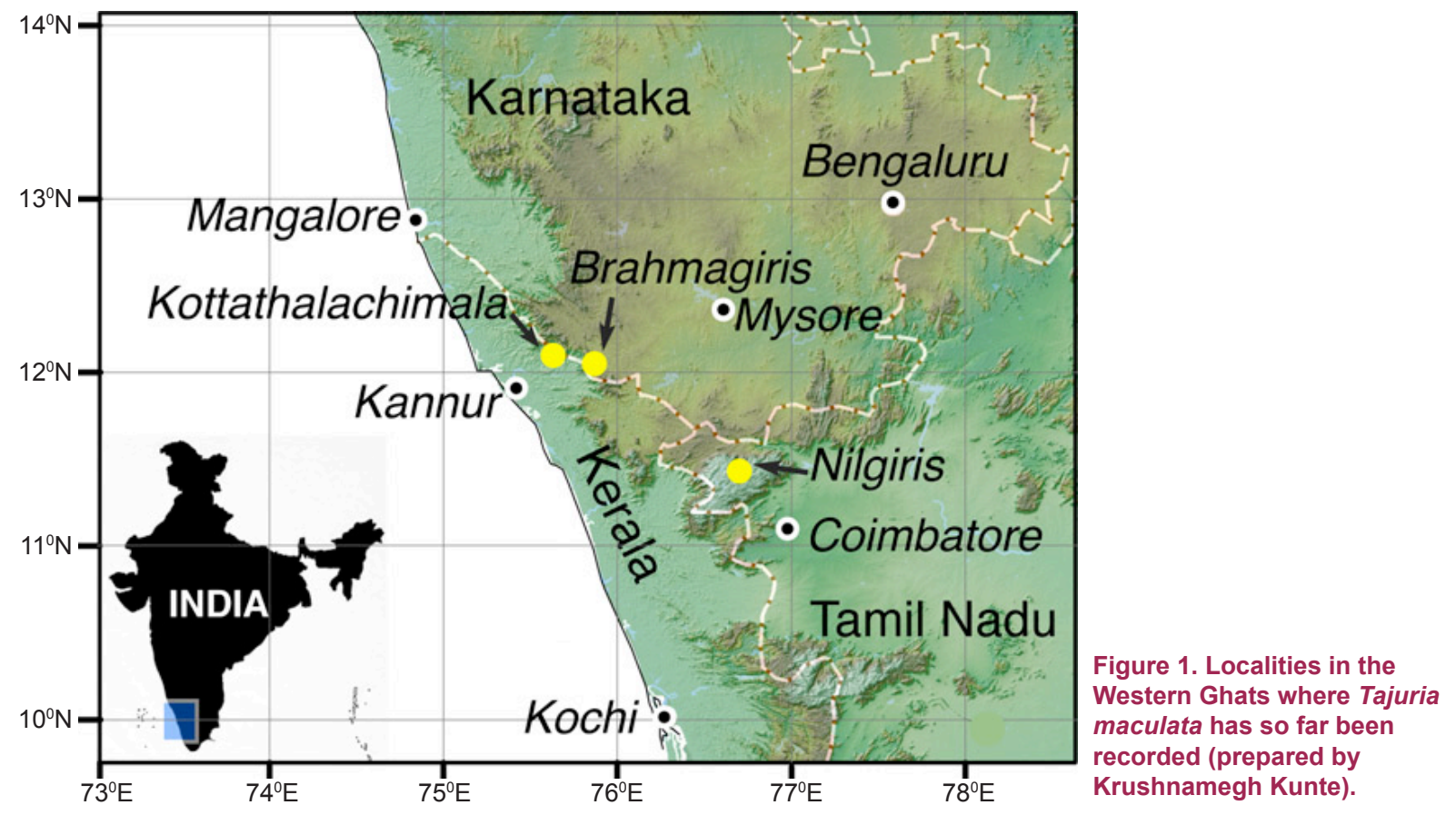

Roberts took from the Nilgiris District, northwestern Tamil Nadu, southern Western Ghats (Yates 1935) (Fig. 1). The collection date and exact locality of this specimen do not seem to have been reported in literature. Considering that a single specimen of $T$. maculata, presumably from the Nilgiris and without any associated information, had ever been collected, Larsen wondered, "If it is indeed a genuinely South Indian species", but noted that, "All the new records to the Nilgiris based on his [Stokes Roberts] material have since been validated by others and the species is so distinctive that it is difficult to see how a labeling error would have survived." (Larsen 1987).

Assuming that the Roberts specimen was indeed collected in the Nilgiris, it was likely collected in the vicinity of either Kotagiri, Coonoor or Udagamandalam ("Ooty") (approximate locations: $11.35-11.43^{\circ} \mathrm{N} \&$ $\left.76.70-76.88^{\circ} \mathrm{E}\right)$, three popular towns in the Nilgiris, from where British entomologists collected most of the Nilgiris butterfly material. There are no other records from the Nilgiris (Wynter-Blyth 1944a,b; Larsen 1987) or from the rest of the Western Ghats (Bell 1910-27). Gaonkar (1996) suspected this species to be present in Kerala, and mentioned the Western Ghats distribution in Tamil Nadu (from the Nilgiris) and Karnataka (possibly from Kodagu, popularly known as Coorg, where some work on butterflies was done by early British lepidopterists). We do not know whether
Gaonkar's (1996) report of this species from Karnataka was extrapolated from the Roberts specimen, or was based on any specimens that have not been reported in print yet. Evans (1932) and Wynter-Blyth (1957) probably either overlooked the Roberts specimen or considered its presence in the Nilgiris improbable, so they did not include the Western Ghats in this species' distribution (Evans 1932; Wynter-Blyth 1957). The Madras Government Museum in Chennai has no specimens from the Western Ghats or from elsewhere in India (Satyamurti 1966).

\section{New observations}

Tajuria maculata was recently seen on two occasions approximately $200 \mathrm{~km}$ northwest of the Nilgiris (Fig. 1). The details are as follows:

(i) Sightings from Brahmagiri Wildlife Sanctuary (Images 2 A \& B): The Brahmagiri Wildlife Sanctuary is located in Kodagu District in the southwestern corner of Karnataka, covering an area of approximately $181 \mathrm{~km}^{2}$. The elevation ranges from 65-1,607 $\mathrm{m}$, the lower slopes and valleys being mostly covered in evergreen and semi-evergreen forests, the upper reaches with a shola forest and grassland mosaic.

VKS and DSD saw four T. maculata individuals in this area on 19 November 2009, a partly cloudy and windy day. The first individual was seen mudpuddling 

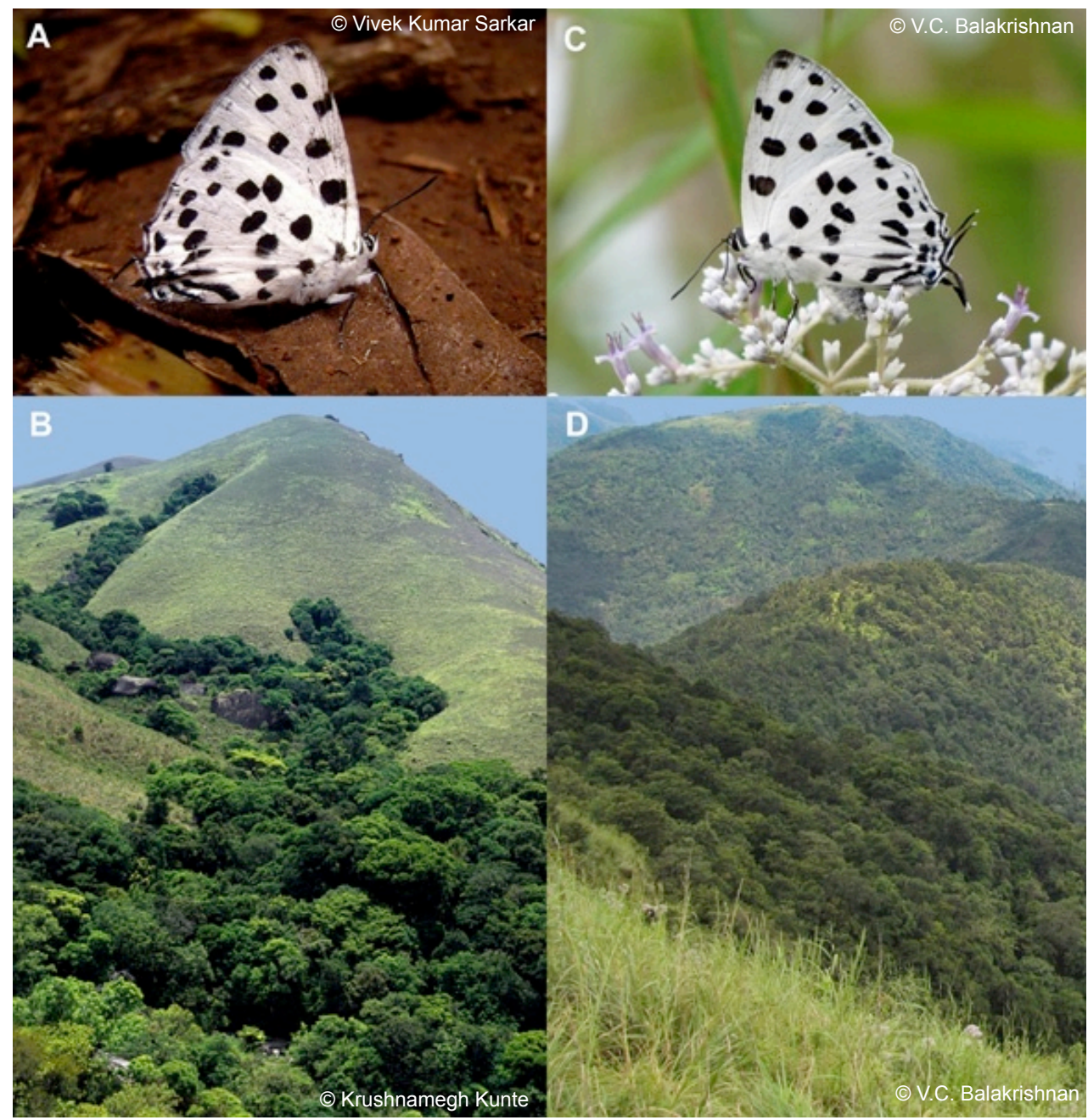

Image 2. Tajuria maculata in the Western Ghats. A - 19.xi.2009, mudpuddling, in the Brahmagiri Wildlife Sanctuary;

B - Habitat at the Brahmagiri, on way to Narimalai Guest House; C - 02.x.2010, feeding from flowers of Knoxia sumatrensis at Kottathalachimala; D - Habitat at Kottathalachimala

(Image 2A) from 1100 to $1130 \mathrm{hr}$ near the Iruppu Falls, a popular tourist destination (approximately 300-500 $\left.\mathrm{m}, 11^{0} 57.8^{\prime} \mathrm{N} \& 75^{0} 58.5 \mathrm{E}\right)$. The other three were seen feeding on white flowers of an unidentified straggling vine in a shola forest patch near the Narimalai Guest House, at $1,300 \mathrm{~m}$. These individuals were feeding well above the ground, constantly chasing each other, and could not be photographed.

(ii) Sighting from Kottathalachimala (Image 2 C \& D): Kottathalachimala is an isolated mountain in Kannur District, northern Kerala. Its summit and the western slopes are covered with grasslands, whereas the eastern slopes are mosaics of semi-evergreen forests and grasslands dominated by Cymbopogon. It is very close to Mundrot Reserve Forest in Karnataka, merely 2 air-kilometers away.

VCB saw a single specimen of T. maculata (Image 2C) at $1313 \mathrm{hr}$ on 2 October 2010, a rainy and misty day with occasionally clear skies. It was seen on the eastern slopes of Kottathalachimala $\left(11^{0} 28.23^{\prime} \mathrm{N}\right.$ \& $75^{0} 78.97^{\prime} \mathrm{E}, 800 \mathrm{~m}$ ), feeding from the flowers of Knoxia sumatrensis (Rubiaceae), which was common there among boulders and grass. It then flew towards the valley and was not seen again. The known larval host plants of $T$. maculata belong to Loranthaceae (http://www.nhm.ac.uk/research-curation/research/ projects/hostplants/), and Dendrophthoe falcata (Loranthaceae) was common in semi-evergreen forest patches at Kottathalachimala. However, VCB did not see any evidence of larval activity on Dendrophthoe plants that he investigated.

\section{Discussion}

Our sightings confirm the occurrence of T. maculata in the Western Ghats. These sightings give credence to the specimen recorded from the Nilgiris by Roberts. They also confirm the presence of this species from the states of Karnataka and Kerala. 
The evergreen forest and montane grassland habitat patches at the Brahmagiri Wildlife Sanctuary are well-protected, so the population of $T$. maculata there is secure. However, large stone quarries have recently been established at Kottathalachimala, which has destroyed some forest and grassland patches. A small cross on the mountaintop is also a popular Easter pilgrimage for local Christians. Together, these two activities cause significant disturbance to wildlife habitats and make the long-term future of the $T$. maculata population at Kottathalachimala uncertain.

\section{REFERENCES}

Bell, T.R. (1910-27). The common butterflies of the plains of India (including those met with in the hill stations of the Bombay Presidency). Journal of the Bombay Natural History Society 19(1)-31(4).

Corbet, A.S., H.M. Pendlebury \& J.N. Eliot (1992). The Butterflies of the Malay Peninsula. $4^{\text {th }}$ Revised Edition. Malayan Nature Society, Kuala Lumpur, 595pp.

de Nicéville, L. (1890). The Butterflies of India, Burmah and Ceylon. Volume III. Lycaenidae. The Calcutta Central Press Co., Calcutta (Kolkata), 503pp.

Evans, W.H. (1932). The Identification of Indian butterflies. $2^{\text {nd }}$ Edition. Bombay Natural History Society, Mumbai, 454pp.

Gaonkar, H. (1996). Butterflies of the Western Ghats with notes on those of Sri Lanka. Report to Centre for Ecological Sciences, Indian Institute of Science, Bengaluru, 89pp.

Hewitson, W.C. (1865). Illustrations of Diurnal Lepidoptera, Lycaenidae. van Vorst, London, 228pp.
Inayoshi, Y. (2010). A Check List of Butterflies in Indo-China (chiefly from Thailand, Laos and Vietnam). <http://yutaka. it-n.jp/>. Accessed 01 Nov. 2010.

Io, C. (ed.) (2000). Monograph of Chinese Butterflies (Revised Edition). Henan Scientific and Technological Publishing House, $845 \mathrm{pp}$.

Larsen, T.B. (1987). The butterflies of the Nilgiri Mountains of southern India (Lepidoptera: Rhopalocera). Journal of the Bombay Natural History Society 84: 291-316.

Larsen, T.B. (2004). Butterflies of Bangladesh - An Annotated Checklist. IUCN Bangladesh Country Office, Dhaka, $147 \mathrm{pp}$.

Pinratana, A. (1981). Butterflies in Thailand. Vol. 4: Lycaenidae. Brothers of St. Gabriel in Thailand, Bangkok, $215 \mathrm{pp}$.

Satyamurti, S.T. (1966). Descriptive Catalog of the Butterflies in the Collection of the Madras Government Museum. The Commissioner of Museum, Chennai, 272pp.

Smith, C. (1989). Butterflies of Nepal (Central Himalaya). Tecpress Service L.P., Bangkok, 352pp.

Swinhoe, C. (1911-1912). Lepidoptera Indica. Vol. IX. Rhopalocera. Family Lycaenidae (continued). Sub-families Horaginae, Deudorixinae, Hypolycaeninae, Zesiusinae, Aphnaeinae, Biduandinae, Cheritrinae, Loxurinae. Family Hesperiidae. Sub-families Ismeneinae, Achalarinae. Reeve \& Co, London, 278pp.

Wynter-Blyth, M.A. (1944a). The butterflies of the Nilgiris (part I). Journal of the Bombay Natural History Society 44: 536-549.

Wynter-Blyth, M.A. (1944b). The butterflies of the Nilgiris (part II). Journal of the Bombay Natural History Society 45: 47-61.

Wynter-Blyth, M.A. (1957). Butterflies of the Indian Region. Bombay Natural History Society, Mumbai, 523pp.

Yates, J.A. (1935). The butterflies of the Nilgiri District. Journal of the Bombay Natural History Society 38: 330-340. 